Neonila Szeszenia-Dąbrowska

Beata Świątkowska

Urszula Wilczyńska

\title{
OCCUPATIONAL DISEASES AMONG FARMERS IN POLAND
}

\author{
CHOROBY ZAWODOWE ROLNIKÓW W POLSCE
}

Nofer Institute of Occupational Medicine / Instytut Medycyny Pracy im. prof. J. Nofera, Łódź, Poland

Department of Environmental Epidemiology / Zakład Epidemiologii Środowiskowej

\begin{abstract}
Background: The study's objective is to present epidemiological situation concerning the incidence of occupational diseases among farmers in Poland. Material and Methods: All 3438 cases of occupational diseases diagnosed among farmers and obligatorily reported to the Central Register of Occupational Diseases (covering all the national territory and all the cases of occupational diseases diagnosed in Poland after 1970) over the years 2000-2014 were subjected to analysis. Results: The annual incidence in the analyzed period ranged 5-14 per 100000 farmers. The analysis showed that about $90 \%$ of pathologies were induced by the biological agents Almost every third pathology due to biological agents had allergic origin. Infectious and parasitic diseases accounted for $62 \%$ of the cases. Among them the diseases carried by ticks (93\%) - borreliosis (85.8\%) and tick-borne encephalitis (7.2\%) were the most frequent ones. The age of farmers, in the case of whom bronchial asthma and allergic rhinitis were diagnosed, was significantly higher than the age of remaining employees of the national economy, in which these occupational diseases were recognized. Conclusions: The study indicates the necessity to introduce periodic health examinations programs focusing on agricultural workers to monitor health and well-being and improve working conditions and the working environment. Med $\operatorname{Pr} 2016 ; 67(2): 163-171$
\end{abstract}

Key words: occupational diseases, epidemiology, borreliosis, incidence, agriculture, employees

\section{STRESZCZENIE}

Wstęp: Celem pracy jest przedstawienie sytuacji epidemiologicznej rolników w Polsce dotyczącej zapadalności na choroby zawodowe. Materiał i metody: Przeanalizowano 3438 przypadków chorób zawodowych, stwierdzonych zgodnie z obowiązującym w Polsce systemem orzeczniczym i obligatoryjnie zgłoszonych w latach 2000-2014 do Centralnego Rejestru Chorób Zawodowych (obejmującego terytorium całej Polski od roku 1970). Wyniki: Zapadalność roczna w analizowanym okresie wynosiła 5-14 przypadków na 100000 pracujących. Około 90\% stwierdzonych patologii wywołały czynniki biologiczne, a niemal co trzecia z tych patologii miała podłoże alergiczne. Choroby zakaźne i pasożytnicze stanowiły $62 \%$ zgłoszonych przypadków. Wśród nich najczęstsze były choroby przenoszone przez kleszcze (93\%) - borelioza (85,8\%) i kleszczowe zapalenie mózgu (7,2\%). Wiek rolników, u których stwierdzono astmę oskrzelową i alergiczny nieżyt nosa, był o ok. 10 lat wyższy niż wiek pracowników z tymi chorobami zawodowymi w pozostałych sektorach gospodarki narodowej. Wnioski: Należy wprowadzić programy okresowych badań profilaktycznych skierowane do osób pracujących w rolnictwie w celu poprawy warunków środowiska ich pracy oraz monitorowania stanu ich zdrowia. Med. Pr. 2016;67(2):163-171

Słowa kluczowe: choroby zawodowe, epidemiologia, borelioza, zapadalność, rolnictwo, pracownicy

Corresponding author / Autorka do korespondencji: Neonila Szeszenia-Dąbrowska, Nofer Institute of Occupational Medicine, Department of Environmental Epidemiology, św. Teresy 8, 91-348 Łódź, Poland, e-mail: wies@imp.lodz.pl

Received: 2015, July 3, accepted: 2015, November 27

\section{INTRODUCTION}

Agriculture belongs to the sectors of economy with a particularly high risk of exposure to factors or work conditions which adversely influence health. The main hazards which accompany work performed on farms include: biological agents (infectious microorganisms, parasites as well as sensitizing), chemical agents (plant protection products and fertilizers) and threats connected with the effect of various physical factors [1-6].

Despite this, occupational diseases in this occupational group are diagnosed less frequently than it would result from the level and frequency of occurrence of adverse work conditions. It is commonly believed that the incidence of occupational diseases among farmers is underestimated. This is especially indicated by 
confrontation of the number and intensity of adverse and burdensome for health factors that occur in the environment of work of farmers with the data on the number of diagnosed occupational diseases. In other occupational groups, in contrary to farmers, the incidence of occupational diseases to a large extent reflects health consequences of occupational exposure (e.g., dust diseases among miners).

The procedure of diagnosing and medical certification of occupational diseases as well the official list of occupational diseases are specified in the currently binding Polish regulations. Both notification and recognition of occupational diseases are governed by the Labour Code Act and the related legal regulations [7,8]. According to the legislation, an occupational disease is defined as a pathology induced by specific factors that are harmful to health and that occur in the environment of work or the way of work performance and is, at the same time, on the official list of occupational diseases. Certification of occupational disease includes:

medical recognition of a pathology, the integral part of which is hygienic assessment of exposure and working conditions,

an administrative decision on recognition of occupational disease, which constitutes a basis of application for financial compensation resulting from the extent of health loss due to the factors imminent in the work environment.

Once the certification procedure is completed, every case of occupational disease is forwarded on a special form by the local sanitary inspector to the Central Register of Occupational Diseases located in the Nofer Institute of Occupational Medicine, Łódź (Poland) where it is registered. The system made it possible to complete a database with all the cases of occupational diseases diagnosed in Poland after 1970.

The currently applying list of occupational diseases, based on the Regulation of the Council of Ministers on occupational diseases of 30 June 2009 [7] includes 26 main positions - names of groups of disease entities. These positions include in total 61 listed entities or pathological changes. The list of occupational diseases that applies in Poland includes the European Union (EU) recommendations concerning the diseases, which are considered as occupational and which are a subject of financial compensations. Diagnosis of occupational disease constitutes a basis for compensation procedure conducted for farmers by the Agricultural Social Insurance Fund (Kasa Rolniczego Ubezpieczenia Społecznego - KRUS).
The aim of this study is to analyze epidemiological situation of occupational diseases as well as to point causative factors which constitute the basis of certification of such diseases in Polish farmers.

\section{MATERIAL AND METHODS}

The analysis included all cases of occupational diseases in farmers, which were obligatorily reported to the Central Register of Occupational Diseases in the Nofer Institute of Occupational Diseases, Łódź (Poland) over the years 2000-2014. All those cases were certified in compliance with the Polish certification system [8]. The study takes into account the information included in the occupational disease recognition sheets: diagnosed disease entities, their causative factors, age and gender of the patients as well as the distribution of incidence according to the voivodeships.

The data was presented in a form of absolute numbers and incidence per 100000 workers. The information concerning the number of individuals working in the national economy being a basis of coefficients calculation was taken from the yearbooks published by the Central Statistical Office (Główny Urząd Statystyczny - GUS). In order to avoid random fluctuations of the annual number of cases, the figures were presented in 3-year periods. The age at recognition of selected occupational diseases was characterized by arithmetic mean (M) and standard deviation (SD). In order to compare two arithmetic means among farmers and other workers we used the Student's t-test.

\section{RESULTS}

In the years 2000-2014 in Poland a downward tendency of occupational diseases was observed, namely the related decrease by 1.8 cases per 100000 employees yearly on average. During the same period the annual incidence of occupational diseases in agriculture increased slightly by 0.7 cases per 100000 workers (Figure 1).

In the last 5 years the average annual incidence of occupational diseases among farmers was expressed in terms of the coefficient equivalent to 12.8 cases per 100000 workers and was lower than the nationwide one, and also than the one observed in several other big national economy sectors (Table 1). During the period included in the analysis, annually reported cases ranged 141-340. Among those who had these diseases diagnosed there was a slight predominance of men. The incidence calculated per 100000 farmers fell into the range of 5-14.6 cases (Table 2). 


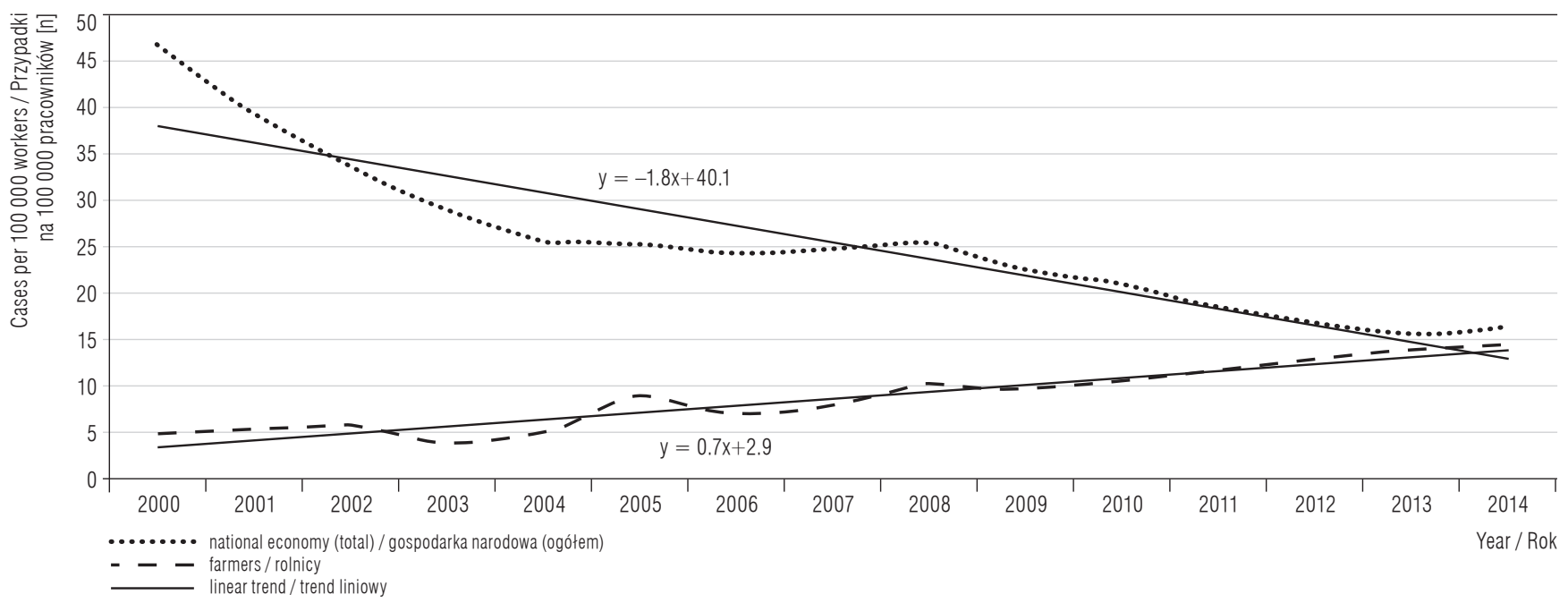

Fig. 1. Occupational diseases among farmers and in all sections of national economy, Poland, 2000-2014

Ryc. 1. Choroby zawodowe wśród rolników i we wszystkich sektorach gospodarki narodowej w Polsce w latach 2000-2014

Table 1. Occupational diseases in Poland, 2010-2014, according to the Statistical Classification of Economic Activities in the European Community (NACE)

Tabela 1. Choroby zawodowe w Polsce w latach 2010-2014 według wybranych sekcji Polskiej Klasyfikacji Działalności (PKD)

\begin{tabular}{|c|c|c|}
\hline $\begin{array}{l}\text { NACE section } \\
\text { Sekcja PKD }\end{array}$ & $\begin{array}{l}\text { Cases } \\
\text { Przypadki } \\
\text { [n/rok] } \\
(\mathrm{M})\end{array}$ & $\begin{array}{l}\text { Rate per } 100000 \\
\text { employed persons, } \\
\text { annual average } \\
\text { Średni roczny współczynnik } \\
\text { na } 100000 \text { pracujących }\end{array}$ \\
\hline Total / Ogółem & 2492 & 17.7 \\
\hline Farming / Rolnictwo & 292 & 12.8 \\
\hline Mining and quarrying / Górnictwo i kopalnictwo & 551 & 314.6 \\
\hline Manufacturing / Przetwórstwo przemysłowe & 665 & 27.4 \\
\hline Construction / Budownictwo & 106 & 12.2 \\
\hline Education / Edukacja & 256 & 23.6 \\
\hline Human health and social work activities / Opieka zdrowotna i pomoc społeczna & 180 & 23.3 \\
\hline
\end{tabular}

NACE - Nomenclature statistique des Activités économiques dans la Communauté Européenne.

Table 2. Incidence rates of occupational diseases among farmers by gender, Poland, 2000-2014

Tabela 2. Zapadalność na choroby zawodowe wśród rolników w Polsce w latach 2000-2014 według płci

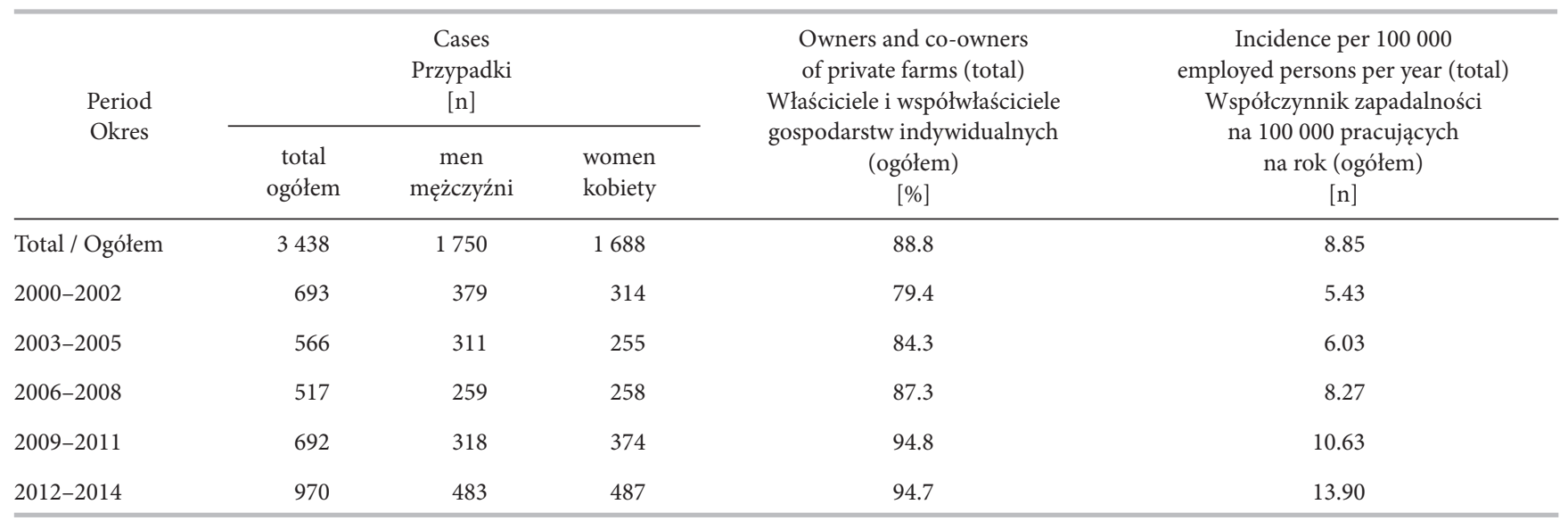


The majority of occupational diseases certified in the individuals working in agriculture concerned individual farmers $(88.8 \%)$. The percentage share of individual farmers in occupational diseases had an increasing tendency, and in recent years it has exceeded $94 \%$. The minority was represented by the employees of farmers' associations, production cooperatives or large specialized farms.

Over the years, the structure of occupational diseases certified in farmers has changed. At the beginning (years 2000-2002), diseases of allergic origin dominated and after 2006 infectious or parasitic diseases started to prevail. Over the years 2012-2014 the related percentage share amounted to $81.4 \%$ of all pathologies (Figure 2).

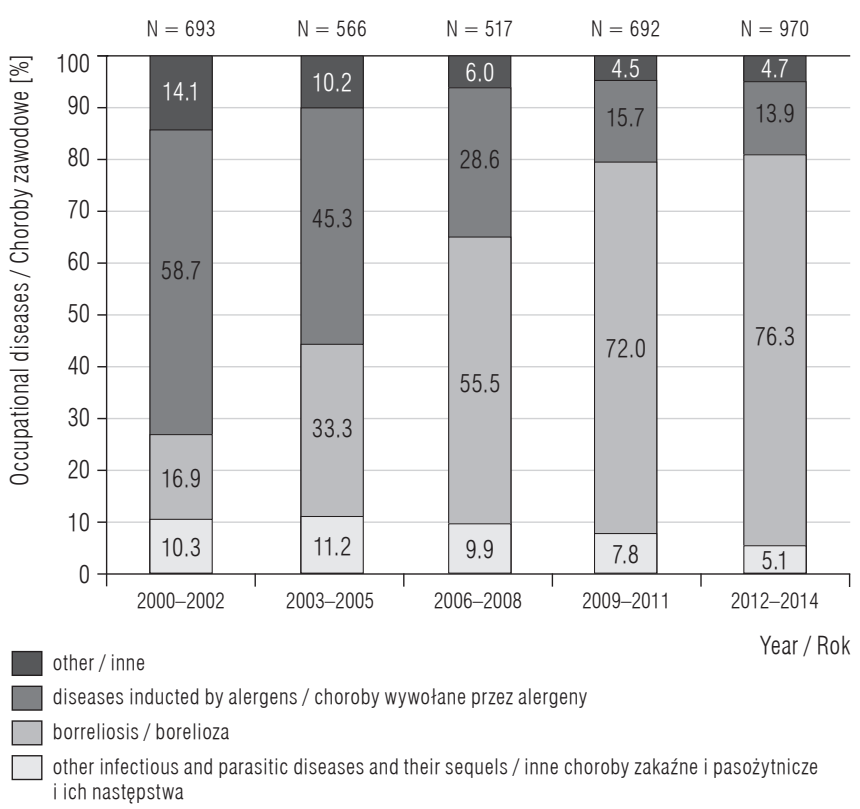

Fig. 2. Occupational diseases among farmers, Poland, 2000-2014 Ryc. 2. Choroby zawodowe wśród rolników w Polsce w latach $2000-2014$

The analysis of 3438 cases, i.e., all the occupational diseases diagnosed in farmers over the years 2000 2014 showed that about $90 \%$ of occupational diseases in farmers was a result of the effect of biological agents viruses, bacteria, parasites, dusts of animal and plant origin, plant products, fungi, yeasts and saprophytes. Physical factors (noise, vibration, ultraviolet radiation, electromagnetic field) caused $3.7 \%$ of the diseases. Chemical agents (among others: rubber components, chromium and nickel compounds, pesticides, oils and lubricants) were considered as causative factor for $3.2 \%$ of all the cases. The way of work performance

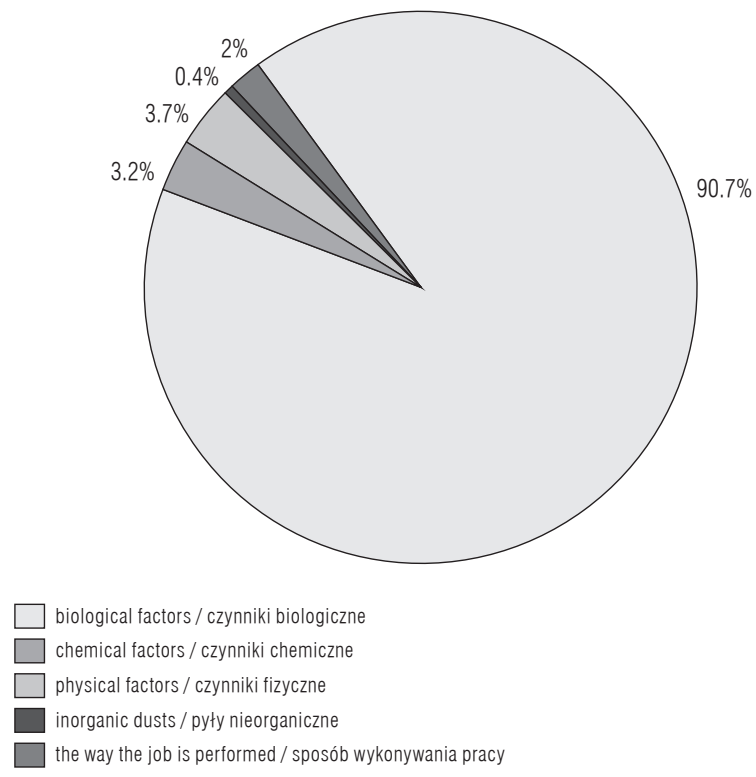

Fig. 3. Causes of occupational diseases among farmers ( $\mathrm{N}=3438)$, Poland, 2000-2014

Ryc. 3. Przyczyny chorób zawodowych wśród rolników $(\mathrm{N}=3438)$ w Polsce w latach 2000-2014

contributed to $2 \%$ of pathologies, and the smallest number of cases was attributed to asbestos dusts, welding dusts and those containing silica $-0.4 \%$ (Figure 3 ).

Among 2300 of the diseases induced by biological agents, infectious and parasitic diseases prevailed (67.4\%). Almost every third (32.6\%) pathology induced by the effect of biological agents had allergic origin.

Chemical agents resulted in 90 pathologies, mostly skin diseases (75.6\%). Intoxications (13.3\%) and malignant neoplasms (4.4\%) were also reported. Other diseases reported in individual cases in total constituted $6.7 \%$ and these were: perforation of the nasal septum, chronic obstructive bronchitis, diseases of visual system, and allergic rhinitis, acute general allergic reactions and extrinsic allergic alveolitis.

In the analyzed period, infectious and parasitic diseases were the most frequent occupational pathologies among farmers and the related percentage share amounted to $62 \%$. In this group diseases carried by ticks - borreliosis (85.8\%) and tick-borne encephalitis (7.2\%) prevailed. Brucellosis (2.6\%) was reported much less frequently. Other diseases, among others: tuberculosis, toxoplasmosis, amebiasis occurred sporadically. More than a half of infectious and parasitic diseases concerned women (51.4\%). The second, in terms of the number of cases, was bronchial asthma (12\%), which was mostly diagnosed among men (56.9\%). 
Dermatoses (7.1\%) were generally diagnosed as contact dermatitis (89\%). Yeast or fungal skin diseases as well as urticaria were reported in 12 people each, and photodermatoses in 3 people. Skin diseases affected mainly women (67.9\%). Allergic rhinitis and extrinsic allergic alveolitis occurred with a similar frequency $(5 \%$ and $5.6 \%$, respectively), and both in majority concerned men (50.6\% and 58.3\%). Hearing loss (3.5\%) was found almost exclusively among men (118/119 cases), whereas diseases of peripheral nervous system (1.3\%) mostly af- fected women (40/46 cases). The remaining 3.5\% of the diagnosed pathologies consisted of 11 different disease groups. The percentage share of each of them did not exceed $0.9 \%$ (Table 3 ).

The mean age of farmers, with diagnosed bronchial asthma as well as allergic rhinitis, was significantly higher than the age of remaining employees of the national economy suffering from these diseases $(\mathrm{t}=5.393, \mathrm{p}<0.001$ and $\mathrm{t}=3.922, \mathrm{p}<0.005$, respectively $)$ (Table 4).

Table 3. Occupational diseases among farmers in Poland in 2000-2014, by nosologic units and gender

Tabela 3. Choroby zawodowe wśród rolników w Polsce w latach 2000-2014 według jednostek chorobowych i płci

\begin{tabular}{|c|c|c|c|c|}
\hline \multirow{2}{*}{$\begin{array}{l}\text { Nosologic unit } \\
\text { Jednostka chorobowa }\end{array}$} & \multicolumn{4}{|c|}{$\begin{array}{l}\text { Cases } \\
\text { Przypadki } \\
\text { [n] }\end{array}$} \\
\hline & $\begin{array}{c}\text { men } \\
\text { mężczyźni }\end{array}$ & $\begin{array}{l}\text { women } \\
\text { kobiety }\end{array}$ & $\mathrm{n}$ & $\%$ \\
\hline $\begin{array}{l}\text { Infectious and parasitic diseases and their sequels / Choroby zakaźne i pasożytnicze } \\
\text { i ich następstwa }\end{array}$ & 1035 & 1096 & 2131 & 62.00 \\
\hline Bronchial asthma / Astma oskrzelowa & 235 & 178 & 413 & 12.01 \\
\hline Skin diseases / Choroby skóry & 79 & 167 & 246 & 7.15 \\
\hline Hearing loss / Ubytek słuchu & 118 & 1 & 119 & 3.46 \\
\hline $\begin{array}{l}\text { Chronic diseases of peripheral nervous system / Przewlekłe choroby obwodowego układu } \\
\text { nerwowego }\end{array}$ & 6 & 40 & 46 & 1.34 \\
\hline Chronic obstructive bronchitis / Przewlekłe obturacyjne zapalenie oskrzeli & 22 & 6 & 28 & 0.81 \\
\hline Chronic diseases of musculoskeletal system / Przewlekłe choroby układu ruchu & 7 & 15 & 22 & 0.64 \\
\hline Diseases of visual system / Choroby układu wzrokowego & 7 & 11 & 18 & 0.52 \\
\hline Vibration syndrome / Zespół wibracyjny & 15 & - & 15 & 0.44 \\
\hline Acute and chronic intoxications and their sequels / Zatrucia ostre i przewlekłe i ich następstwa & 8 & 6 & 14 & 0.41 \\
\hline Nasal septum perforation / Przedziurawienie przegrody nosa & - & 1 & 1 & 0.03 \\
\hline $\begin{array}{l}\text { Diseases of central nervous system, heart stimulating and conducting system and } \\
\text { gonads - induced by electromagnetic fields / Choroby centralnego układu nerwowego, } \\
\text { bodźcotwórczego i przewodzącego serca oraz gonad wywołane działaniem pól } \\
\text { elektromagnetycznych }\end{array}$ & - & 1 & 1 & 0.03 \\
\hline
\end{tabular}


Table 4. Occupational diseases among farmers and other workers in Poland in 2000-2014, by nosologic units and age Tabela 4. Choroby zawodowe wśród rolników i innych pracowników w Polsce w latach 2000-2014 według jednostek chorobowych i wieku

\begin{tabular}{|c|c|c|c|c|}
\hline \multirow[b]{2}{*}{$\begin{array}{l}\text { Occupational disease } \\
\text { Choroba zawodowa }\end{array}$} & \multicolumn{2}{|c|}{$\begin{array}{l}\text { Farmers } \\
\text { Rolnicy }\end{array}$} & \multicolumn{2}{|c|}{$\begin{array}{l}\text { Other workers } \\
\text { Inni pracownicy }\end{array}$} \\
\hline & $\begin{array}{c}\text { cases } \\
\text { przypadki } \\
{[\mathrm{n}]}\end{array}$ & $\begin{array}{c}\text { age } \\
\text { [years] } \\
\text { wiek } \\
\text { [w latach] } \\
(\mathrm{M} \pm \mathrm{SD})\end{array}$ & $\begin{array}{c}\text { cases } \\
\text { przypadki } \\
{[\mathrm{n}]}\end{array}$ & $\begin{array}{c}\text { age } \\
\text { [years] } \\
\text { wiek } \\
{[\text { w latach] }} \\
(\mathrm{M} \pm \mathrm{SD})\end{array}$ \\
\hline $\begin{array}{l}\text { Infectious and parasitic diseases and their sequels / Choroby zakaźne i pasożytnicze } \\
\text { i ich następstwa }\end{array}$ & 1203 & $50.9 \pm 8.7$ & 2130 & $50.7 \pm 10.1$ \\
\hline Bronchial asthma / Astma oskrzelowa & 52 & $50.8 \pm 7.0$ & 194 & $43.0 \pm 12.1$ \\
\hline Allergic rhinitis / Alergiczny nieżyt nosa & 20 & $51.5 \pm 8.3$ & 147 & $41.4 \pm 11.6$ \\
\hline $\begin{array}{l}\text { Extrinsic allergic alveolitis / Zewnątrzpochodne alergiczne zapalenie pęcherzyków } \\
\text { płucnych }\end{array}$ & 81 & $49.0 \pm 8.9$ & 10 & $49.8 \pm 10.3$ \\
\hline Skin diseases / Choroby skóry & 41 & $47.0 \pm 8.6$ & 382 & $46.6 \pm 11.0$ \\
\hline $\begin{array}{l}\text { Musculoskeletal diseases and diseases of peripheral nervous system / Choroby } \\
\text { układu mięśniowo-szkieletowego i choroby obwodowego układu nerwowego }\end{array}$ & 36 & $51.4 \pm 7.2$ & 1425 & $52.1 \pm 7.3$ \\
\hline
\end{tabular}

\section{DISCUSSION}

The annual incidence of occupational diseases among farmers manifested itself by means of the coefficient equivalent to 12.8 cases per 100000 workers and was lower than the nationwide incidence and the one observed in several other large sections of the national economy.

Agriculture is an economy sector, in which the number of adverse for health risk factors is considerably high, however the data on occupational diseases, except of infectious diseases, does not reflect the actual number of consequences of threats associated with the working process in this occupational group. The big number of cases of diseases carried by ticks, especially borreliosis, among farmers is a reflection of large incidence of this disease in the whole Polish population. Over the years 2010-2014, the percentage share equivalent to $4.8 \%$ of the cases of the incidence of all borreliosis recorded nationwide was considered to be associated with the performed occupational work [9]. Due to the lack of vaccine against borreliosis it is necessary to promote protective measures i.e., suitable clothing and repellents among individuals who are occupationally exposed to tick bites.

The link between agriculture and disease has long been established but recognizing of occupational origin of health problems causes many problems in the medical practice. The particularly underestimated diseases are the cases of occupational diseases with allergic origin and diseases of the musculoskeletal system, which - due to the exposure and work conditions - are potentially the most frequent pathologies connected with work in an agricultural farm.

Occupational diseases of the musculoskeletal system and ailments on the side of motor system caused by disorders of peripheral nervous system constitute a major clinical and social problem which is one of the main reasons behind temporary and long-term disability to work. In 2001, in the EU countries musculoskeletal system diseases along with the diseases of peripheral nervous system were top ranked, accounting for $43 \%$ of all the reported occupational diseases [10].

In Poland, over the years 2000-2014 these pathologies accounted for only $2.9 \%$ of the whole structure of occupational diseases, and among farmers - for $1.8 \%$ of it. The results of a recently published study indicate considerable certification problems in a group of diseases induced by the way of work performance within the context of considering such a type of pathologies as occupational diseases. Only $1 / 3$ of the reported suspicions of occupational diseases of motor system and peripheral nervous system ended up with medical certification of occupational disease and issuing an administrative decision on recognition of occupational disease [11].

Bronchial asthma in economically developed countries is the most common occupational respiratory disease. The general feeling is that the actual number of cases of occupational asthma is significantly underestimated [12]. 
In the United Kingdom (UK), it is assumed that the underestimation value equals $1 / 3$ of new cases [13]. The occupational fraction of the overall incidence of asthma among adults is estimated at $10-15 \%[14,15]$, while in the developed and rapidly developing countries those fractions are estimated at $13-14 \%$ and in the poor countries the corresponding value is $6 \%$ [16]. In Sweden, the fraction of occupational asthma among men is estimated at $29 \%$, and among women at $17 \%$ [17]. In 12 European Union countries in 2001, the cases of asthma accounted for $23.8 \%$ of all occupational lung diseases [18]. In Belgium, in the years 19932002, the incidence of occupational asthma per year averaged 2.9/100 000 with the downward trend of about 3.6 in 1993 to 2.6 in 2002 [19]. The reduction in the recorded cases is the trend recently observed on a global scale. In Scandinavia, the annual incidence remains at a high level of about 18/100 000 employees, while in underdeveloped countries about 2 cases are recorded per 100000 employees $[16,20]$.

Bronchial asthma in Poland in 2014, representing the rate of $0.4 / 100000$ employees accounted for $5 \%$ of all occupational respiratory diseases. The large variation in the incidence of asthma among the countries is due to the lack of strategies for identification of potential allergenic factors and cases of the disease in the work environment, and the lack of standardized diagnostic methods and surveillance systems [21,22] which, according to the presented data, in our country urgently require improvement.

Chronic obstructive bronchitis (averagely 1 case a year during the last 10 years) which is extremely rarely diagnosed as an occupational disease, despite a high risk of occurrence of this pathology among those working in agriculture as referred to in other studies, draws attention [23-25]. Undoubtedly, the reason is the restrictive definition of this pathology recognition as an occupational disease, limited to the cases of permanent and substantial impairment of lung ventilation and at the same time incomprehensible reference to the hygienic criterion for previously mentioned cases of exceeding maximum admissible concentration (MAC) in the workplace.

Underestimation of the number of occupational diseases among farmers is a result of not recognizing (under-recognition of) occupational pathology by a physician [26,27]. Numerous occupational diseases are diagnosed and recognized too late. This is confirmed by the older age of the farmers who had occupational disease diagnosed in comparison with the age of other employees of the national economy with analogical occupational pathologies (in the case of bronchial asthma and allergic rhinitis - longer than 10 years). In a number of cases no actions are taken in order to recognize occupational disease. The reasons for such a situation should be sought in systemic factors of the certification-compensation process as well as the extent of farmers being interested in recognizing an occupational disease. There is no doubt that low awareness of country people and lack of knowledge of general health care practitioners concerning the diseases induced by environmental factors are of great importance.

In Poland agricultural property remained mostly in the hands of private individuals. The important obstacle in the process of recognizing occupational diseases in this occupational group is the lack of health status monitoring and not including individual farmers in the system of prophylactic medical care with regard to the performed work [28]. Hence, it is necessary to involve farmers in medical examination carried out by occupational physicians, which enable farmers to equitably take advantage of health care and social insurance that apply in other sectors of the national economy.

Additionally, in the light of currently binding legislation individual farms are not included in the organizational-legislative system in terms of supervision of the environment of work analogical to other workplaces. This makes assessment of working conditions and further performance of procedures concerning occupational risks in the workplace impossible. In this situation, the job exposure matrix, developed similarly as in the case of other branches of national economy, for a specific job position in agriculture would be helpful [29].

However, a major strength of this study is that the analysis was based on the data collected in the Central Register of Occupational Diseases covering all the national territory and all the cases of occupational diseases diagnosed in Poland after 1970. Systematic collection of the data on occupational diseases is important for well-informed occupational policies, prevention and compensation.

\section{CONCLUSIONS}

Due to the lack of vaccine against borreliosis it is necessary to provide education about the mode of tick transmission and promote personal protective measures against tick exposure (e.g., wearing specific types of clothing, using repellents, frequent checks for ticks). 
The study indicates the necessity to introduce periodic health examinations programmes focusing on agricultural workers to monitor health and well-being and improve working conditions and the working environment.

\section{REFERENCES}

1. Mołocznik A, Zagórski J. Exposure to dust among agricultural workers. Ann Agric Environ Med. 1998;5(2):127-30.

2. Śpiewak J. [Occupational skin diseases among self-employed farmers]. Postepy Dermatol Alergol. 2004;21(6): 278-85. Polish.

3. Dutkiewicz J, Cisak E, Sroka J, Wójcik-Fatla A, Zając V. Biological agents as occupational hazards - Selected issues. Ann Agric Environ Med. 2011;(2):286-93.

4. Solecki L. [Back pain in the lower spine among farmers exposed to general vibration - A literature review]. Med Pr. 2011;62(2):187-202. Polish.

5. Osborne A, Blake C, Fullen BM, Meredith D, Phelan J, McNamara J, et al. Risk factors for musculoskeletal disorders among farm owners and farm workers: A systematic review. Am J Ind Med. 2012;55(4):376-89, http:// dx.doi.org/10.1002/ajim.22001.

6. Karttunen JP, Rautiainen RH. Distribution and characteristics of occupational injuries and diseases among farmers: A retrospective analysis of workers' compensation claims. Am J Ind Med. 2013;56(8):856-69, http:// dx.doi.org/10.1002/ajim.22194.

7. [The regulation of the Council of Ministers of 30 June 2009 on the occupational diseases. J Laws 2009, No. 105, item 869]. Polish.

8. [The regulation of the Minister of Health of 24 May 2012 on documenting occupational diseases and their effects. J Laws 2012, item 663]. Polish.

9. National Institute of Public Health. [Infectious diseases and poisonings in Poland (annual report). 2010, 2011, 2012, 2013, 2014]. Warszawa: The Institute [cited 2015 June 8]. Available from: http://wwwold.pzh. gov.pl/oldpage/epimeld/2015/index_mp.html. Polish.

10. Karjalainen A, Niederlaender E. Occupational diseases in Europe in 2001. Stat Focus. 2004 [cited 2015 June 8]; 15:1-8. Available from: http://ec.europa.eu/eurostat/ documents/3433488/5316393/KS-NK-04-015-EN.PDF/ 05b3b108-3589-4044-aba2-63e2403f6e0a.

11. Cwynar E, Kosińska M, Tomczyk-Socha M. [Analysis of notifications of suspicions of diseases caused by the way the job is performed in the context of pathologies regarded as occupational diseases]. Med Pr. 2013;64(3):387-96, http://dx.doi.org/10.13075/mp.5893.2013.0033. Polish.
12. Kogevinas M, Antó JM, Sunyer J, Tobias A, Kromhout H, Burney P. Occupational asthma in Europe and other industrialised areas: A population-based study. European Community Respiratory Health Survey study group. Lancet. 1999;353(9166):1750-4, http://dx.doi.org/10. 1016/S0140-6736(98)07397-8.

13. Ayres JG, Boyd R, Cowie H, Hurley JF. Costs of occupational asthma in the UK. Thorax. 2011;66(2):128-33, http://dx.doi.org/10.1136/thx.2010.136762.

14. Gautrin D, Newman-Taylor AJ, Nordman H, Malo J-L. Controversies in epidemiology of occupational asthma. Eur Respir J. 2003;22(3):551-9, http://dx.doi.org/10.1183/ 09031936.03.00047803.

15. Nelson DI, Concha-Barrientos M, Driscoll T, Steenland K, Fingerhut M, Punnett L, et al. The global burden of selected occupational diseases and injury risks: Methodology and summary. Am J Ind Med. 2005;48(6): 400-18, http://dx.doi.org/10.1002/ajim.20211.

16. Jeebhay MF, Quirce S. Occupational asthma in the developing and industrialised world: A review. Int J Tuberc Lung Dis. 2007;11(2):122-33.

17. Karjalainen A, Kurppa K, Martikainen R, Klaukka T, Karjalainen J. Work is related to a substantial portion of adult-onset asthma incidence in the Finnish population. Am J Respir Crit Care Med. 2001;164(4):565-8, http:// dx.doi.org/10.1164/ajrccm.164.4.2012146.

18. Karjalainen A, Niederlaender E. Occupational diseases in Europe in 2001. Stat Focus. 2004:15:1-8.

19. Vandenplas O, Lantin AC, D'Alpaos V, Larbanois A, Hoet P, Vandeweerdt M, et al. Time trends in occupational asthma in Belgium. Respir Med. 2011;105(9):136472, http://dx.doi.org/10.1016/j.rmed.2011.05.002.

20. Karjalainen A, Kurppa K, Virtanen S, Keskinen H, Nordman $\mathrm{H}$. Incidence of occupational asthma by occupation and industry in Finland. Am J Ind Med. 2000;37(5): 451-8, http://dx.doi.org/10.1002/(SICI)1097-0274(200005) 37:5<451::AID-AJIM1>3.0.CO;2-U.

21. Lombardo LJ, Balmes JR. Occupational asthma: Review. Environ Health Perspect. 2000;108 Suppl 4:697-704, http://dx.doi.org/10.1289/ehp.00108s4697.

22. Leira HL. Occupational asthma in Norway. Tidsskr Nor Laegeforen. 2008;128(23):2719-21.

23. Melbostad E, Eduard W, Magnus P. Chronic bronchitis in farmers. Scand J Work Environ Health. 1997;23(4): 271-80, http://dx.doi.org/10.5271/sjweh.220.

24. Radon K, Garz S, Riess A, Koops F, Monso E, Weber C. Respiratory diseases in European farmers - II. Part of European farmers, project. Pneumologie. 2003;57(9):510-7.

25. Szczyrek M, Krawczyk P, Milanowski J, Jastrzębska I, Zwolak A, Daniluk J. Chronic obstructive pulmonary 
disease in farmers and agricultural workers - An overview. Ann Agric Environ Med. 2011;18(2):310-3.

26. Zagórski J. [A critical assessment of current solutions in health protection of individual farmers]. In: Zagórski J, editor. [Occupational and para-occupational diseases in agriculture]. Lublin: Instytut Medycyny Wsi; 2000. p. 40-8. Polish.

27. Zagórski J, Jastrzębska J. [Occupational risks in individual farming. Characteristics of threats in the selected types of farms according to the Polish Classification of Economic Activities]. Lublin: Instytut Medycyny Wsi; 2002. Polish.

28. Jastrzębska J, Zagórski J. [The principles of diagnosis and certification of occupational diseases in individual farmers]. Mat Stud. 2001;4:25-32. Polish.

29. Mannetje AM, McLean DJ, Eng AJ, Kromhout H, Kauppinen T, Fevotte J, et al. Developing a general population job-exposure matrix in the absence of sufficient exposure monitoring data. Ann Occup Hyg. 2011;55(8):879-85, http://dx.doi.org/10.1093/annhyg/mer045.

This work is available in Open Access model and licensed under a Creative Commons Attribution-NonCommercial 3.0 Poland License / Ten utwór jest dostępny w modelu open access na licencji Creative Commons Uznanie autorstwa - Użycie niekomercyjne 3.0 Polska - http://creativecommons.org/ licenses/by-nc/3.0/pl/deed.en. 